\title{
LEADERSHIP DEVELOPMENT IN UKRAINE IN THE CONTEXT OF EDUCATIONAL TRENDS OF WESTERN EUROPEAN COUNTRIES
}

\author{
Roman Storozhev \\ Ph.D., Doctoral Student at the Department of Parliamentary and Political Management, \\ National Academy of Public Administration under the President of Ukraine, Ukraine \\ e-mail: ris03021976@ukr.net,orcid.org/0000-0001-5103-7274
}

\section{Summary}

At the current stage of Ukrainian state integration into European community, country leaders face new challenges that require improving efficiency of public management and public administration based on democracy and human-centeredness. Urgency of public leadership development in Ukraine is closely related to the foreign countries' experience study on the mechanisms of formation and development of public leadership, characterized by a high level of moral values, responsibility, communication, modesty. The new management paradigm, being introduced in public administration and public management in Ukraine, also requires introduction of new qualities in public leadership, manifested through establishment of moral values in the leader's personality, leader's behavior in public service reform. According to the author, such qualities of leadership as delegation of powers in public authorities, intersectoral cooperation in public administration determine development of leadership in the context of educational trends in foreign countries.

The author believes that today an important aspect in the development of public leadership is the mobilization aspect of the efforts of all leaders and subordinates of public authorities and leaders of civil society institutions to overcome crises and do complex reforms in public administration. Such crises include ensuring stability in global fight against the GOVID-19 pandemic. However, problem of public leadership development in this aspect has not been properly reflected in modern scientific sources.

The article reveals priority models of public leadership of Western European countries as a prerequisite for formation of successful personality, successful leadership qualities, the trend of which is such an important factor as publicity, because before the 90 s of the twentieth century not all government officials in European countries were public.

Keywords: leadership models, leadership qualities, personality of the leader, typology of leadership, current stage of Ukrainian state integration into European community

DOI: https://doi.org/10.23856/4221

\section{Introduction}

Focus on leadership transparency in Western European countries has been part of a major shift in the role of senior officials, as they have been expected to demonstrate public leadership (E. Page and V. Wright, 2017). This was one of the important trends in the development of leadership as officials until the 90 s of the twentieth century. not all were public.

In the article, we will consider features of development of public leadership in Scandinavian countries - Sweden, Denmark, the Kingdom of Netherlands, Norway; Switzerland and the Federal Republic of Germany. After all, new management paradigm, actively implemented in domestic public administration, requires formation of new qualities in public leadership, which 
are manifested through assertion of moral values of the individual, his behavior in communication, self-management, stressful situations. Such leadership qualities as ability to self-educate, delegation of authority, transparency (transparency, openness and activation) and transformational cooperation determine a new style of leadership development in Western European countries, which will be useful for implementation in Ukraine.

\section{Developmental features of public leadership in the Scandinavian countries}

The Scandinavian countries are a bright example of how to build a model socio-political system with a highly developed economy, a high standard of living, respect for rights and freedoms in fairly harsh climatic conditions.

Kingdom of the Netherlands determines that one of the important human factors of a person involved in public administration, adaptation to new challenges is personal "quality". Therefore, bureaucracy in this country is required to have continuous training, in particular in the field of e-democracy. There is no doubt that information and communication technologies, opening new opportunities not only for modernization but also for greater transparency in activities of the government and leadership, contribute to increasing democratic participation of citizens in the political life of the state and development of leadership.

In this context, much attention is paid to continuing education, distinguishing between long-term programs aimed at particular career and short-term training for specific tasks or jobs. What is the connection and interaction between the government, public and private universities on the training of public servants (F. Meer, A. Kerkhoff, D. Osch, 2017).

We should also highlight one more feature of political and administrative system of the Netherlands that influences development of leadership, describing this feature as interaction between politicians and officials. Yes, politicians with administrative experience, after completing their political careers, in most cases hold administrative positions at various levels. It is this experience that gives officials the opportunity for understanding, contributing to effective interaction and formation of leadership teams in public administration. It is obvious that principle of publicity reveals personality of the leader, accompanied by acquisition / change of ideas about his professionalism, values, implementation as a manager, etc., which may define / not define the leader as a person to be followed.

Sweden is one of the most innovative and cooperative countries in the world, presenting itself as a global leader of changes to promote and support the concept of sustainable development. Success of this concept requires coordinated efforts of the entire system of public administration, according to which the country's development policy is based on a unique mix of innovation and cooperation. So-called policy labs help government agencies meet the needs of society, successfully make regulatory changes and facilitate innovations that will stimulate social sustainable development (Van der Hoven R.2017).

Main providers of public services in Sweden are local municipalities, whose work is based on the following principles: democracy - all public power is exercised through people by universal vote, representative democracy and parliamentary system; obedience to the lawpublic authorities must strictly abide the law; objectivity - impartiality and equal treatment of all people; freedoms - free formation of opinions and freedom of expression; respect - public authority must be exercised through respect for freedom and equality of every human being; efficiency and service - activities of public sector should be carried out cheaply and with the highest possible quality, as soon as possible, given the available resources (Swedish Council for Strategic. 2019). 
According to the current constitutional legislation of Sweden, right to establish system of public administration, status of the civil service and its conditions is given to the Riksdag, management of administrative structures of the center and the local level is done by the government.

The first group includes "political officials"- ministers, their deputies, heads of government departments, prosecutors, governors, police chiefs etc. It is specific that the basic composition of senior and middle administrative staff does not depend on the political orientation of the government, and therefore is unchanged. For such employees, promotion is permissible, but transfer against their will or dismissal before reaching the established age is not allowed. Municipalities are independent of the central government and determine financial status and staffing at their own reasonable discretion. Their employees do not belong to civil servants group, at the same time there is no such thing as "the rank of civil servants" (Swedish Council for Strategic. 2019).

Civil servants are required to have high professional level and relevant personal qualities. Training of civil servants in Sweden is carried out in universities, their education has traditionally been economic or legal, corresponding the essence of Anglo-Saxon approach to education. However, when receiving professional education, civil servants have a strong training in the field of law, but improving the quality of work is associated with application of interdisciplinary approach, which expands their opportunities for successful management.

Application of training programs in the context of interdisciplinary approach, allows you to develop and improve systematic and critical thinking, communication skills, self-organization, creativity, teamwork skills, etc., undoubtedly contributing to development of leadership.

Turning to analysis of officials' professional development in Norway, we see no retraining. They adhere to imperative that winning the competition gives every specialist a reason to fully perform their professional duties. At the same time, the system of advanced training of public servants is built mainly on self-education. This applies to the process of self-acquisition of knowledge and skills individually and during all types of courses.

So, in order to make a career, take senior position in Norway, become a leader, improve your financial well-being, you have to study continuously.

A Norwegian public official can apply to educational institution and study on his / her own. Such services are most often provided by Higher Public Schools, conducting free courses on democracy development, involvement of citizens in the development of society, creation of conditions for self-development, self-realization, training of leaders, etc. The defining form of professional development is self-education, which develops leadership by providing important competencies. In performance of functional duties, quality of their implementation directly depends on the ability of an employee to self-educate, which is considered a standard of public service (Meer, F.M. van de, Kerkhoff, A.D.N., Osch, D.A.G.T. van. 2014: 22-25).

\section{Development of transformational leadership in Switzerland and Germany}

Switzerland is a federal parliamentary republic, its public administration is governed by provisions of the Constitution (1999), basic principles of which are respect for federalism and democracy.

Swiss governance is based on fundamental principles such as neutrality and direct democracy. Practice has shown that transfer of powers from the center to cantons and communities increases the efficiency of public administration in the country. An important achievement of Swiss democracy are various tools of direct democracy, allowing citizens to be active in referendums, legislative initiatives, elections, public meetings of voters and more. Civil servants 
and their leaders need to introduce new ways and methods of leadership that allow them to most fully perform their tasks. This also means lifelong learning is necessary, and it can be carried out in leading higher educational institutions. One of them, in the system of professional training of civil servants and their leaders, is the Institute for Advanced Training in Public Administration (Institute for Advanced Studies in Public Administration - IDHEAP).

This institute trains government officials, their management and those who plan to work in the public sector after graduation. IDHEAP curricula are approved at the level of confederation, and the Master's degree in Public Administration has been accredited by the European Public Administration Accreditation Association. Training of students in IDHEAP is carried out within the framework of the main programs: master's degree in public administration, as well as public management and policy, doctorate in public administration (Faculté de droit. 2015). Next to teaching, IDHEAP conducts research and consulting on public administration, professional training for members of administrative bodies, aimed at developing leadership.

One of the features of Switzerland is great attention paid to recruitment of future civil servants. Selection of candidates in the public administration system takes place in open competition and interviews with potential direct management. The search uses well-known social networks Facebook, Linkedin, as well as specialized portals, in particular: Federal jobs portal: www.stelle.admin.ch/stelle/fr/home.html, specializing in recruiting civil servants. Among other important requirements of recruiters for future officials is professional education that matches the position; higher education corresponding the level of bachelor, master or doctor.

Prerequisites also include national languages, each municipal employee must speak at least two languages (71\% German, 22\% French, 7\% Italian). Personal qualities, ability and wish to continuously learn and self-improve are also taken into account. (Van der Hoven R. 2017).

Germany has a system of educational institutions that deal with advanced training of civil servants. Federal Academy of Public Administration under the Ministry of Internal Affairs takes the key spot in it. Special in this process is the general direction of training, not associated with transfer of knowledge, rather with development of a certain way of thinking and behavior of employees.

In advanced training, preference is given to practical classes, rather than lectures or other classes in the room. Therefore, internships take place both at work and abroad.

Priority is given to interactive teaching methods, under the guidance of teachers, aimed at organizing discussions, brainstorming, "round tables" for individual or collective search for solutions to various problems that arise or may arise during their professional activities. Civil servants develop the habit of improving competence in the process of independent learning through problem-solving method.

Advanced training of senior civil servants - leaders-managers is carried out at the Federal Academy of Public Administration of Germany. A wide range of curricula, thematic plans and other materials for self-study allows students to create methodological tools to support the self-educational activities of the head (official) throughout his career. It is important for educational programs to be built on a modular principle, making them flexible. There is an opportunity to create various training courses and programs that meet public needs - specific community or certain area. The content of training programs informs the employee about the knowledge and trends in the field of his activity, encouraging the participants to master them (Kalashnyk N. S.2013:48).

Therefore, in order to confirm the right for a higher position and to pursue a successful career, there is a need for continuing education. Interesting fact is that compulsory subjects are studied in specialized educational institutions of public administration, and electives - law 
of a particular land, relevant innovative technologies and development strategies, including leadership, are studied by a public servant independently. It noteworthy that to replace a senior position one must pass a qualifying exam.

High School of Public Administration in Germany has a European Institute - the Institute for Cross-Border Cooperation with France, and the High School itself maintains numerous partnerships with institutions in other countries (Poradnyk iz suchasnoho ta efektyvnoho upravlinnya lyuds'kymy resursamy. 2013: 12). Active, real and continuous self-education creates conditions to confirm the status of a civil servant, influencing development of leadership, which contributes to his career advancement.

\section{Analysis of developmental trends in public administration of Poland}

In recent decades, a perfect system for civil servants' training has been developed in Poland. However, reaching such result was not easy. With the beginning of administrative reform in the 1990s in Poland, due to implementation of the New Public Administration Concept, there was an urgent need for appropriate civil service personnel and its leadership, who could ensure clear and organized implementation of changes in state building.

1. The main legislative act regulating process of training civil servants is the Constitution of Poland (April 1997), defining main tasks of the civil service, namely: "ensuring professional, high-quality, impartial and politically neutral performance of the state tasks." (p. 153) (Kuc B.R., Moczydłowska J.M. 2009 :146).

The Law on Civil Service (1996, 1998, 2006, 2008, 2015), in addition to important issues of building public administration, defines approaches to the civil servants' training. In particular, the Law defines following types of training of civil servants: central training, general training, training as part of individual program of professional development of a civil servant, special training. Training for civil servants is organized in order to deepen knowledge and develop skills necessary to perform tasks of the civil service. Each type of training has its own goals

Central training is organized for civil servants in order to support and implement tasks of the civil service; dissemination of the principles of civil service and principles of ethics of civil servants; dissemination of personnel management standards; developing ability to coordinate work at the level of governing bodies and between them; dissemination of knowledge necessary to perform civil service tasks.

General training is organized in order to develop knowledge and skills of civil servants, which are essential for the successful performance of civil service tasks.

Training as a part of individual program of the civil servant' development is organized to acquire knowledge and skills outlined by the specified program.

Special training is organized in order to deepen and update the knowledge and skills of civil servants in the field related to tasks of the management bodies. (Rozporzadzenie Prezesa Rady Ministrów z dnia 24 czerwca 2015 r. 2015; Ustawa z dnia 18 grudnia 1998 r. o stużbie cywilnej. 1998; Ustawa z dnia 21 listopada 2008 r. o stużbie cywilnej. 2008; Ustawa z dnia 24 sierpnia 2006 r. o stużbie cywilnej. 2016).

Among important documents that define special policy for the training of civil service professionals in Poland, it is worth noting two documents such as: "Educational policy of the civil service" (2012) («Polityka szkoleniowa w służbie cywilnej») and "Directives on implementation of civil service training policy” (2012) («Wytyczne dotyczące wdrażania Polityki szkoleniowej w służbie cywilnej») (Polityka szkoleniowa w stużbie cywilnej. 2012; Wytyczne dotyczące wdrażania Polityki szkoleniowej w służbie cywilnej.2012). 
The first document is theoretical, the second - practical. The first presents analysis of the current functioning state of civil service, the second - a collection of practical instructions, showing step by step how to better build an effective internal system of civil servants. These documents introduced special policy for training civil service professionals, facilitated the search for ways to develop and plan careers of civil servants, and training activities provided in it are aimed at effectively filling the gaps in civil service, which is undoubtedly important for high quality of services to the population.

It is also worth noting that the special policy on training of civil servants is constantly being improved.

\section{Educational trends of Poland to work in the European Union structures}

2. In the context of special policy on the civil servants training, special attention is paid to the training of civil service leaders. Due to preparation of civil servants for active participation in the structures of the European Union and introduction of managerial model in public administration, which required a new type of civil servant, the so-called change leader, able to activate other people to perform tasks. (Rozporządzenie Prezesa Rady Ministrów z dnia 24 czerwca 2015 r. 2015).

In 2002 were trained the following offices - staff of the Office of the Prime Minister were trained; Ministry of Finance; Ministry of Economy; Ministry of Labor and Social Policy; Ministry of Agriculture and Rural Development; Ministry of Justice; Ministry of Interior and Administration; Ministry of Foreign Affairs; Ministry of Environment; Ministry of Health; Masovian and Silesian Voivodeships within the framework of the European program "Strengthening Management Capabilities" with such partner institutions as: Office of the Council of Ministers of Great Britain and Northern Ireland, Public School of Public Administration of the Kingdom of Denmark, National Institute of Public Administration of the Kingdom of Spain. (Działania Urzędu Stużby Cywilnej mające na celu poprawe funkcjonowania administracji publicznej. 2011).

In 2003, annual studies were organized for CEOs as representatives of strategic personnel of public administration in order to deepen knowledge in the field of application the rule of law and fair management methods, as well as formation of leadership competencies and managerial skills. Topics of the courses included problems of civil service functioning, observance of legislative procedures, administrative law, problems of organization, management, supervision and control (Gierelo K. 2003:134).

In 2004, the European project "Raising the awareness of members of the public administration corps on ethical dilemmas" was implemented with participation of the Greek consortium Center for the European Constitution- Themistocles \& Dimitris Tsatsos Founion i Diadikasia Business S.A. (Plan szkoleń centralnych w stuzbie cywilnej na 2011 r. 2012).

In 2003-2004, trainings were organized to strengthen Polish management administration and develop corps of leaders in order to effectively implement public administration standards. Among issues addressed during the training were: access to public information, customer service techniques in public institutions, quality management of customer service, challenges for modern leader of a public institution, strengthening innovation of public administration, principles of public dialogue, etc.

In 2007-2009, the Civil Service Department under Operational Human Capital Program (Priority V "Good Governance"), co-financed by the European Social Fund, implemented a project: "Training of people appointed to high government positions". Purpose of the project 
was to form leadership qualities in the heads of government agencies, organizations and departments. (Plan szkoleń centralnych w stużbie cywilnej na 2011 r. 2012).

To reach this goal, a central training was organized "Modern leadership in public organization of change - the role of leadership positions in the civil service" (Nowoczesne przywództwo w organizacji publicznej na rzecz zmian - rola wyższych stanowisk w służbie cywilnej) (Nowoczesne przywództwo w organizacji publicznej na rzecz zmian - rola wyższych stanowisk $w$ stużbie cywilnej. 2013). for employees having positions in the civil service, who introduce significant changes in the functioning of the state, economics and society.

In 2014, trainings were organized for employees of the Office of the Prime Minister, various ministries and voivodships) on the topic: "Ethics, anti-corruption and conflicts of interest in order to provide elected leaders of the civil service with relevant knowledge that would contribute to ethics and transparency of managing administration (Tomaszwska A., Szymański R. Szkolenia centralne w 2014 r. 2014: 14).

In 2018, central trainings of civil service leaders (employees of ministries and voivodship administrations) took place within the framework of forming a culture of decency and honesty in civil service in order to support their performance of functions of ethical leaders. Classes took various forms: lectures, practical classes in groups, discussions, role-plays, coaching, situation analysis, etc. (Plan szkoleń centralnych w stużbie cywilnej na 2018 r. 2019).

The National School of Public Administration plays a special role in training leaders in Poland (Krajowa Szkoła Administracji Publicznej im. Prezydenta Rzeczypospolitej Polskiej Lecha Kaczyńskiego) im. Prezydenta Rzeczypospolitej Polskiej Lecha Kaczyńskiego). This higher education institution is not typical for Poland. It was established in 1989 in response to radical changes in the country at the time. The aim was to create a new type of European-style educational institution that would strengthen Polish civil service. The National School is subordinated to the Chairman of the Council of Ministers of Poland, trains staff for local self-government and senior civil servants of Polish administration, trains and retrains civil service personnel, including leaders. Purpose of the National School of Public Administration is to train highly professional employees of administration and leaders of public administration (Kempa B. 2017).

Politicians, scientists, graduates of the school note positive aspects of its activities. For example, regular meetings of civil servants-practitioners, leaders of public administration are interesting. The first such meeting of "Community of Human Management Practitioners" ("Wspólnota Praktyków ds. HR (Human Resources) in public administration" took place in 2013. These meetings raise various issues related to human resource management (law, ethics, corruption, economics, social issues) with participation of students of the National School of Public Administration (Oferta szkoleń 2018).

\section{Conclusion}

Thus, analysis of foreign experience in leadership development within the context of educational trends in foreign countries (experience of Sweden, Norway, the Netherlands, Switzerland, Germany, Poland) shows that European integration has led to interactions in this process. The outlined unanimity is revolving around understanding and awareness of civil servants, managers-leaders importance of lifelong learning, importance of recruitment and non-admission to this cohort of random, unprofessional people. This allows us to assert the idea of importance of updating the experience and educational trends of European countries and creative adaptation of them in Ukraine. 


\section{References}

An Introduction to Shared Values for Civil Servants / Swedish Council for Strategic Human Resources Development. Retrieved from: https://www.his.se/PageFiles/3429/Shared\%20Values\%20for\%20Civil\%20Servants.pdf [in Swedish]

Chappelet J.-L. Trends in Swiss Civil Servants Training. CSPTC 2017. Retrieved from: http:// www.csptc.gov.tw/ hrd/2017/images/speech3.pptx [in English]

Działania Urzędu Stużby Cywilnej mające na celu poprawe funkcjonowania administracji publicznej. Retrieved from: https://www.nik.gov.pl/plik/id,1556.pdf [in Poland]

Faculté de droit, des sciences criminelles et d'administration publique Retrieved from: http:// www.idheap.ch/idheap.nsf/vwbasedocuments/idmpa01 [in French]

Gierelo K. (2003) Wizerunek (image) - teoria i praktyka. Wrocław: Wyd. Uniwersytetu Wrocławskiego. [in Poland]

Kalashnyk N. S. (2013) Samoosvita dezhavnykh sluzhbovtsiv: kompetentnisnyy pidkhid : monohrafiya [Self-education of state employees: competence approach: monograph]. Dnipro. [in Ukrainian]

Kempa B.: Celem KSAP jest kształcenie przyszłych liderów. Retrieved from: http://www. radiomaryja.pl/informacje/b-kempa-celem-ksap-ksztalcenie-przyszlych-liderow [in Poland]

Kuc B.R., Moczydłowska J.M. (2009) Zachowania organizacyjne. Warszawa: Wydawnictwo Difin S.A. [in Poland]

Meer F.M. van de, Kerkhoff, A.D.N., Osch, D.A.G.T. van. (2014) Educating and training civil servants in the Netherlands 1814-2014. IIAS Administrative History Conference, Corfu, April 26, 2014. Corfu, Greece: IIAS Administrative History study group, pp. 20-25. [in English] Nowoczesne przywództwo w organizacji publicznej na rzecz zmian - rola wyższych stanowisk w stużbie cywilnej. Retrieved fromL: https:// www.dsc.kprm.gov.pl/sites/default/files/skrypt-_ gamma.pdf [in Poland]

Oferta szkoleń 2018. Retrieved from: http://ksap.gov.pl/ksap/sites/default/files/files/oferta_ szkolen_2018_0.pdf [in Poland]

Plan szkoleń centralnych w stużbie cywilnej na 2011 r. Retrieved from: https://dsc.kprm.gov.pl/ sites/default/files/plan_szkolen_centralnych_w_sluzbie_cywilnej_na_2011_r.pdf [in Poland]

Plan szkoleń centralnych $w$ stużbie cywilnej na 2018 r. Retrieved from: https://dsc.kprm.gov.pl/ sites/default/files/plan_szkolen_centralnych_w_sluzbie_centralnych_na_2018_rok.pdf [in Poland]

Polityka szkoleniowa w stużbie cywilnej. Retrieved from: https://dsc.kprm.gov.pl/sites/default/ files/pliki/zal.nn_2.pdf [in Poland]

Poradnyk iz suchasnoho ta efektyvnoho upravlinnya lyuds'kymy resursamy. Rada Yevropy [Guide to modern and effective human resource management]. Council of Europe: 2013. P. 26 [in Swedish].

Rozporzadzenie Prezesa Rady Ministrów z dnia 24 czerwca 2015 r. w sprawie szczegółowych warunków organizowania i prowadzenia szkoleń w stużbie cywilnej. Retrieved from: http:// prawo.sejm.gov.pl/isap.nsf/download.xsp.pdf [in Poland].

Rozporzadzenie Prezesa Rady Ministrów z dnia 24 czerwca 2015 r. w sprawie szczegółowych warunków organizowania i prowadzenia szkoleń w stużbie cywilnej. Retrieved from: http:// prawo.sejm.gov.pl/isap.nsf/download.xsp/WDU20150000960/O/D20150960.pdf [in Poland]

Tomaszwska A., Szymański R. (2014) Szkolenia centralne w 2014 r. Przegląd Stużby Cywilnej. no. 4(31). lipiec-sierpień. pp. 14. [in Poland] 
Ustawa z dnia 18 grudnia 1998 r. o stużbie cywilnej. Retrieved from: http://prawo.sejm.gov.pl/ isap.nsf/DocDetails.xsp?id=WDU19990490483 [in Poland]

Ustawa z dnia 21 listopada 2008 r. o stużbie cywilnej. Retrieved from: http://prawo.sejm.gov.pl/ isap.nsf/download.xsp/WDU20170001889/U/D20171889Lj.pdf [in Poland]

Ustawa z dnia 24 sierpnia 2006 r. o stużbie cywilnej. Retrieved from: http://prawo.sejm.gov.pl/ isap.nsf/DocDetails.xsp?id=WDU20061701218 [in Poland]

Ustawa z dnia 5 lipca 1996 r. o stużbie cywilnej. Retrieved from: http://prawo.sejm.gov.pl/isap. nsf/DocDetails.xsp?id=WDU19960890402 [in Poland]

Van der Hoven R. La formation europeenne destine aux hauts fonctionnaires des Etats mwmbers de I'Union europeenne Rutger van der Hoven Available from internet. Retrieved from: http: //www.eipa.eu /en/eipascode/downloadarticle/\&tid=1633 [in Poland]

Wytyczne dotyczace wdrażania Polityki szkoleniowej w stużbie cywilnej. Retrieved from: https:// dsc.kprm.gov.pl/sites/default/files/pliki/zal._nr_3.pdf [in Poland] 